\title{
A UN Architecture to Build Peace in Post-Conflict Situations
}

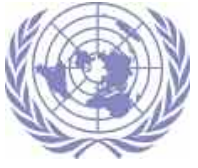

\section{BY EJEVIOME ELOHO OTOBO}

OVER THE LAST DECADE, the international community has learned that the countries most likely to lapse into conflict are those that have been there before. Studies have shown that about half of all countries that emerge from violent conflict relapse into violence within ten years. Recognizing that much more effort has to be devoted to consolidating the peace after it has been won, leaders at the 2005 World Summit created the institutional arrangements of the UN Peacebuilding architecture.

\section{- Peacebuilding Architecture overview}

THE UN PEAGEBUILDING ARGHITEGTURE (PBA) is the latest in a series of efforts to reform the way the UN supports conflict-affected countries, in particular those at the post conflict end of the spectrum. It consists of three components: the Peacebuilding Commission, the Peacebuilding Fund and the Peacebuilding Support Office.

The Peacebuilding Commission (PBC), the institutional lynchpin of the architecture, is an inter-governmental advisory body to the Security Council and the General Assembly mandated to:

\section{TABLE 1: PEACEBUILDING PRIORITIES IDENTIFIED IN THE STRATEGIC FRAMEWORKS}

\section{COUNTRY}

$\begin{array}{ll} & \text { Promotion of good governance; comprehensive } \\ \text { Ceasefire Agreement between Government of Burundi } \\ \text { and PALIPEHUTU-FNL; security sector reform; justice, } \\ \text { promotion of human rights and action to combat } \\ \text { impunity; the land issue and socio-economic } \\ \text { recovery; mobilization and coordination of } \\ \text { international assistance; subregional dimension; and } \\ \text { gender dimension. }\end{array}$

Youth employment and empowerment; justice and

Sierra Leone $\left(2007^{*}\right) \quad$ security sector reform; consolidation of democracy and good governance; capacity-building; energy sector; and subregional dimensions of peacebuilding.

\begin{tabular}{ll} 
& $\begin{array}{l}\text { Elections and institution-building for the National } \\
\text { Electoral Commission; measures to jump-start the } \\
\text { economy and rehabilitate infrastructure, in particular } \\
\text { the energy sector; security sector reform; } \\
\text { strengthening of the justice sector, consolidating the } \\
\text { rule of law and fighting against drug trafficking; } \\
\text { public administration reform and modernization; and } \\
\text { social questions critical for peacebuilding. }\end{array}$ \\
$\begin{array}{l}\text { Central African Republic } \\
\left(2009^{*}\right)\end{array}$ & $\begin{array}{l}\text { Reform of the security sector and disarmament, } \\
\text { demobilization and reintegration; governance- } \\
\text { rule of law; and development poles. }\end{array}$ \\
\hline * Year that the Strategic Framework was adopted between the PBC and the Country.
\end{tabular}

- Bring together all relevant actors and to advise on integrated strategies for post-conflict peacebuilding and recovery;

- Help to marshal resources and ensure predictable financing for immediate post-conflict activities and sustained financial investment over the medium- to longer-term;

- Extend the period of attention by the international community to post-conflict recovery;

- Develop and disseminate best practices in support of countries emerging from conflict.

Currently the PBC has four countries on its agenda: Burundi, Sierra Leone, Guinea Bissau, and the Central African Republic. There are five ways in which the Commission is putting into practice its mandate in these countries.

First, the PBC has brought together in a single forum all major stakeholders relevant for each country's peacebuilding process, i.e. the UN, international financial institutions, countries contributing troops, major donor countries, neighboring countries, regional organizations and institu- 
tions, and the permanent members of the UN Security Council.

Second, the Commission has articulated an integrated peacebuilding approach between interventions meant to restore peace and security and those aimed at reconstruction and development in these countries.

Third, the PBC is sustaining international political and financial support to these countries well beyond the evaporation of the "CNN effect." Fourth, the PBC seeks to ensure that all stakeholders engaged with these countries collaborate around an agreed upon integrated strategy, or a "roadmap" for peace consolidation, developed jointly by national authorities and the Commission. Table I shows the key peacebuilding challenges and priorities identified in the strategic frameworks agreed upon by the PBC and the four countries currently on its agenda. Finally, through its Working Group on Lessons Learned, the Commission seeks to capture and disseminate good practices from the experiences of post-conflict countries for broader application to countries on the agenda of the PBC and in similar situations.

The second component of the architecture, the Peacebuilding Fund (PBF), is under the authority of the UN Secretary General and is administered by the Peacebuilding Support Office. The PBF combines the scope of a global fund with the country-specific focus of a multi-donor trust fund. It is designed to quickly release resources needed to launch peacebuilding activities in countries emerging from conflict and to bridge funding gaps in pertinent areas. As of May 2009, a total sum of $\$ 312.7 \mathrm{~m}$ has been pledged to PBF against an initial target of US\$250m. To date, allotments have been made to twelve countries. Table II provides a summary on the key aspects of the Fund.

Both $\mathrm{PBC}$ and $\mathrm{PBF}$ are supported by a Peacebuilding Support Office (PBSO) which is part of the UN secretariat. The PBSO is a small non-operational office headed by an Assistant Secretary General who reports directly to the Secretary General. The Office supports the work of the PBC, manages the PBF and advises the Secretary General on UN system-wide peacebuilding strategies and policies.

\section{Peacebuilding Architecture- a promising beginning}

SINGE THE PEAGEBUILDING ARCHITECTURE is only in its third year of operation, it may be too soon to make a definitive assessment regarding fulfilling its mandate and meeting the high expectations that led to its creation. However, it is fair to say that the peacebuilding architecture has achieved some successes.

A commonly agreed element of the PBC's value-added is its contribution to developing integrated strategies for peacebuilding, based on genuine partnerships between national and international actors. Such strategies have been completed in all four countries on the agenda of the PBC. The strategies have provided the basis for "compacts" between the various national actors, in particular the government, and the international community. These are monitored at biannual review meetings which provide a forum for inclusive dialogue amongst all partners. The PBC has also provided concrete advice and recommendations to other UN organs, including the Security Council and the Executive Boards of UN Funds and Programs. The PBC has also played a key role in advising operational actors on the necessary sequencing and prioritization of peacebuilding efforts in Central African Republic and Guinea Bissau, in which such strategies were adopted in the past nine months.

The Commission seeks to galvanize international support for and improve coherence of peacebuilding efforts in countries on its agenda. For example, it convened the High-Level Stakeholders Consultation on Sierra Leone in May 2008, at which senior representatives of member states, the UN, IFIs, the private sector and civil society gathered and thus broadened the donor base for Sierra Leone. The Commission also played this role effectively in Burundi by keeping the spotlight on the peace process and working with regional actors to encourage both sides of the conflict to adhere to prior agreements. The Commission was also instrumental in mobilizing resources to bridge the funding gaps for the November 2008 Presidential elections in Guinea Bissau and is actively working to mobilize support for economic development and security sector reforms in that country. Similarly, the commission is currently engaged in promoting international support for disarmament, demobilization and reintegration in Central African Republic, as an integral part of sustaining national political reconciliation and creating an enabling environment for growth and development.

PBC's approach of sustained attention is predicated on the principles of national ownership, partnership and mutual accountability. As Burundi, Guinea Bissau, Central African Republic and Sierra Leone, have demonstrated, the PBC engages in active partnership with national authorities, providing a platform for incorporating and supporting their interaction with international partners. The Commission has also fostered dialogues among national authorities and local civil society actors active in peace consolidation efforts, most notably in Burundi.

Despite these initial successes in sustaining international attention for countries on its agenda, the PBC is cognizant of the challenges which must be addressed as it moves forward.

One of such challenges for the Commission will be to determine when a country "graduates" from its agenda. Emerging evidence suggests that peacebuilding results must be measured in decades or even generations, not years. The PBC has a valuable role to play in helping national and international partners build knowledge about the use of benchmarks and milestones in the peacebuilding process. The second challenge is strengthening its effort to mobilize resources for countries on its agenda, beyond allocations by the PBF.

As for the PBF, it has demonstrated its value not only as an instrument to support post-conflict peacebuilding but also as a tool to address problems that could lead to potential lapse or relapse into conflict. Yet, we have also learned that the Peacebuilding Fund may have been too slow in disbursing funds. Some of its problems can be attributed to "teething," 
TABLE 2: PBF KEY FIGURES: PEACEBUILDING FUND ALLOCATIONS AND PROJECTS APPROVED AS OF MAY 15, 2009

\begin{tabular}{|c|c|c|c|c|}
\hline \multirow{2}{*}{ WINDOW } & \multirow{2}{*}{ COUNTRY } & \multirow{2}{*}{ Allocation USD } & \multicolumn{2}{|c|}{ Projects Approved } \\
\hline & & & $\#$ & USD \\
\hline \multirow{5}{*}{ PBF WINDOW I } & Burundi & $\$ 35,000,000$ & 17 & $\$ 32,836,315$ \\
\hline & Central African Republic & $\$ 10,000,000$ & 12 & $\$ 10,000,000$ \\
\hline & Guinea Bissau & $\$ 6,000,000$ & 4 & $\$ 5,686,889$ \\
\hline & Sierra Leone & $\$ 35,000,000$ & 14 & $\$ 32,669,828$ \\
\hline & TOTAL PBF WINDOW I & $\$ 86,000,000$ & 47 & $\$ 81,193,032$ \\
\hline \multirow{6}{*}{ PBF WINDOW II } & Comoros & $\$ 9,000,000$ & - & - \\
\hline & Côte d'Ivoire & $\$ 5,000,000$ & 2 & $\$ 5,000,000$ \\
\hline & Guinea & $\$ 6,000,000$ & - & - \\
\hline & Liberia & $\$ 15,000,000$ & 20 & $\$ 14,287,394$ \\
\hline & Nepal & $\$ 10,000,000$ & - & - \\
\hline & TOTAL PBF WINDOW II & $\$ 45,000,000$ & 22 & $\$ 19,287,394$ \\
\hline \multirow[t]{2}{*}{$\begin{array}{l}\text { PBF WINDOW III } \\
\text { Emergency } \\
\text { Projects }\end{array}$} & $\begin{array}{l}\text { Projects funded in Burundi; } \\
\text { Central African Republic; Côte } \\
\text { d'Ivoire; Guinea; Haiti; Liberia } \\
\text { and Kenya (more details) }\end{array}$ & $\$ 6,353,903$ & 8 & $\$ 7,353,903$ \\
\hline & $\begin{array}{l}\text { TOTAL PBF WINDOW III } \\
\text { Emergency }\end{array}$ & $\$ 6,353,903$ & 8 & $\$ 7,353,903$ \\
\hline \multicolumn{2}{|c|}{ PBF WINDOW I, II \& III } & $\$ 137,353,903$ & $77^{*}$ & $\$ 107,834,329$ \\
\hline
\end{tabular}

but others are systemic, and related to implementing arrangements in fragile post-conflict situations characterized by weak implementation capacities. However, the Fund's greatest potential is not that of a "main funder" of peacebuilding projects but that of a "catalyst" for new approaches and commitments to peacebuilding. Another significant feature of the Fund is the fact that funding decisions are decentralized to a national-level steering committee which includes government, civil society, private sector, the UN, donors and, in most cases, the World Bank. In some cases, this has led to improved national ownership, forging new partnerships, and building a common agenda for peacebuilding.

\section{Strengthening partnership in support of post-conflict countries}

ENHANCED GOLLABORATION and strategic partnership between the PBC and IFIs, and other institutional donors, holds much promise. From the inception of the Commission, it was agreed that the World Bank, the International Monetary Fund and other institutional donors should participate in all PBC meetings. The PBC provides the best platform for the
World Bank to engage with other stakeholders in determining critical peacebuilding priorities, sequencing and coordination of peacebuilding efforts.

As a consequence of its unique composition and working methods, the $\mathrm{PBC}$ represents a major forum to coordinate international support to countries emerging from conflict. It is also the most suitable forum to facilitate greater collaboration between security, political and development actors, thus advancing the World Bank's notion of "securing development." The PBC could also support the follow-up to and implementation of the World Bank-UN Partnership Framework for Crisis and Post-Crisis Situations signed in 2008 by the Secretary General and the President of the World Bank.

The PBA has taken the important first steps to achieve its key objectives of supporting countries in transition from conflict to sustainable peace, bridging institutional gaps in the post-conflict reconstruction and development within the UN, and advancing the broader international community's peacebuilding effort. Indeed, early experience suggests that the PBA is off to a promising start.

Ejeviome Eloho Otobo is Director and Deputy Head, UN Peacebuilding Support Office. 


\section{PARTNERING FOR A HARMONIZED, ALIGNED RESPONSE IN FRAGILE STATES}

\section{THE PRINCIPLES FOR GOOD INTERNATIONAL ENGAGEMENT IN FRAGILE STATES (FS) EXHORT INTERNATIONAL ACTORS TO:}

harmonize their activities in fragile states through, for example, joint upstream analysis, assessments, shared strategies, and coordinated political engagement.

take an integrated approach to politics, security, and development challenges.

In the spirit of these principles, the Bank has catalyzed its partnerships with the UN (in a Partnership Framework), the International Network on Conflict and Fragility (INCAF) of the Development Assistance Committee of the Organization for Economic Cooperation and Development, the African Development Bank and European Union (and International Monetary Fund) on budget support, and the United Nations Development Programme on state building.

\section{THE UN-WORLD BANK PARTNERSHIP FRAMEWORK}

The need to formalize a partnership framework with the UN arose from recognition that the Bank and the UN have complementary roles in fragile states, but that previous ad hoc working arrangements caused delays and inefficiencies. These retarded the speed and coherence of international response.

These principles are operationalized through two documents:

A UNDG-WB Operational Annex which anchors a common operational platform for coordinated post-crisis responses, including common methodologies and tools (such as the Post-Conflict Needs Assessment and the Post-Natural Disaster Needs Assessments)

The Fiduciary Principles Accord (FPA) between concerned UN agencies and the World Bank. Any agency signing the FPA can use its own fiduciary rules when implementing projects financed under emergency trust funds administered by any other signatory. This should reduce implementation delays.

\section{THE OECD-DAC'S INCAF}

The Bank co-chairs the INCAF task team on Peace-building, State-building and Security and participates in the Financing and Aid Architecture task team.

In the first case, co-chairing enables the Bank to bring its perspective to linkages between statebuilding and peace-building, and thus between security, institutions, and development. In the group on transitional financing, the Bank helps deepen knowledge on the availability of finance during a conflictaffected state's transition period to sustained peace. The group reviews donor instruments available during the transition, assesses financing gaps, and identifies risk management strategies to ensure delivery of rapid and flexible financing in context of fragility.

\section{JOINT WORK ON BUDGET SUPPORT WITH THE EC AND AFDB}

The Bank is working with the EU and the AfDB (with the IMF acting as "interested" peer reviewer) to review past experiences with, and recommend a set of common principles for, budget support in fragile situations. Five focus countries (Central African Republic (CAR), Sierra Leone, Burundi, GuineaBissau, and Haiti) have been selected, and a comparative analysis between them and budget support experience in non-fragile situations is being undertaken to draw out best practices. A "statement of principles" to harmonize budget support practice will be applied to the CAR case.

\section{JOINT INITIATIVE ON STATE BUILDING WITH THE UNDP BUREAU OF CRISIS PREVENTION \& RECOVERY (BCPR)}

This initiative aims to support national actors and the UNDP and World Bank (WB) programs in their on-going efforts to support state-building processes in fragile states. Experiences with capacity development in support of state building, and how UNDP and WB inputs are furthering state building, will be reviewed. Two countries-Sierra Leone and Liberia - are being reviewed as case studies as part of this initiative. The review of past experience will be complemented by an action plan for additional measures to improve effectiveness of UNDP and WB efforts in this important area of international support to fragile states. 